tion of inventions is neglected in many cases. Waste and by-products useful in certain industries are being neglected, while other industries could put many of them to good use, and have, in fact, been wanting some of these products. There appeared to be lack of co-ordination of efforts in industries engaged on similar work.

In short, problems which have been engaging the attention of scientific men in Great Britain, and many of which have been solved, are being experienced in Australia also.

The results of the debates were crystallized in ten resolutions which are now being communicated to the appropriate authorities. It is hoped that action will be taken by the Government. The Australian Association of Scientific Workers proposes to watch developments, and will make use of its special knowledge to see that better use is made of Australian scientific resources and man-power.

\section{PACIFIC RELATIONS IN THE POST- WAR WORLD}

$\mathrm{T}$ HE second of the series of reports on the United States in a new world, based on the findings of a committee of the editors of Time, Life and Fortune set up to study post-war problems, is of particular interest as indicating the trend of advanced American thought on Pacific relations. The proposals are based on a belief in the greatness of Asia, and on the view that progress towards free and more abundant life in times of peace must be mainly concerned with a practical solution of the problems of productivity, literacy and common law and order, and that the East needs the social inventions of the West just as much as its technology. It is assumed that in the largest degree the peoples of Asia must work out their own solution, and the preference for strong and effective international authority is clearly indicated; although it is recognized that the United States may, in certain circumstances, have to be the principal trustee of the United Nations, while others are growing into modernity or recovering from the consequences of the War. The report proposes an organization to be called the Pacific Council, which would be the final judicial authority of the United Nations on Pacific affairs, although for the co-operative international administration required in specific jobs, the organization of special co-operative bodies is suggested, representing only those members of the United Nations which have a legitimate interest in the specific tasks.

The first of these tasks proposed is that of creating a nation in South-Eastern Asia. Coupled with an independent Philippines, it is suggested that new States should be created out of the other ex-colonies of Indonesia. The first and largest of these States would consist of Thailand, British Malaya, all the British and Dutch Islands in Indonesia and Portuguese Timor, with the political status of an international republic, in which it is suggested the ability and responsibility of the Dutch Colonial administrators will find ample scope. For the creation of this State the ultimate reasons are military and economic. In regard to Burma, it is suggested that Great Britain should transfer its rights to an international commission, on which Great Britain, India, China and the
United States would be strongly represented, which would conclude an agreement with China concerning its transit rights on the Burmese roads, railways and rivers, and in the port of Rangoon. The first task of this commission would be that of physical reconstruction. It is suggested that France might be induced to agree to a similar course for Indo-China, after the preliminary restoration of French sovereignty.

While long-term control and disarmament of Japan is not considered feasible, it is suggested that if an American-Chinese-British-Dutch Group took over the Japanese aviation monopoly and its installations under a contract to run for 25-50 years, its operation would preclude any effective secret Japanese rearmament. Transfer of Japanese investments in Manchuria and China to China is suggested, and control of Japan's merchant marine should be vested in a Combined Shipping Board. The best hope for a change of heart in Japan is regarded as lying in the total discrediting of its military leaders and their followers, and in a resulting resolve of the Japanese people themselves to oust them.

With regard to China, the more serious specific problems to be solved are those of agriculture, industrialization, the restoration of an economic industrial balance, transport and education. All these principal problems are interrelated and formidable, but the building of a strong and free China is a Chinese task. The interdependence of China and other nations including the United States is recognized, however, and industrialization can only come naturally as part of a general international expansion if China is certain that such international economic expansion will occur, as expansion depends fundamentally on American participation. The approach to post-war economic relations can only be freed from mutual suspicion by a better understanding of the facts. The Chinese problem is to secure the essential financial and technical assistance from abroad, without paying for it through impaired sovereignty or the loss of control over national resources. The report strongly supports the participation in a free market area open to every nation, and Chinese exports should not be debarred from American markets by high duties. Economic relations with China require the admission of Chinese goods in payment of Chinese obligations, and the cheap imports would benefit the general United States public.

The danger to American industry and standards of living is discounted, and it is considered that one article of the mutual aid agreement should keep Asiatic, and especially Chinese, protectionism within bounds. These are the general principles for future and long-range application, and immediate measures should be taken with these objects in view. Reconstruction grants on a minor scale should greatly assist co-operation in the field of higher education, and the services of highly skilled scientific men and technicians are likely to be in very high demand in post-war China. The report frankly faces the changes in the American immigration law, which, like changes in the tariff, will be required. Leading problems of Korea, India, the South Pacific and New Zealand are briefly reviewed, and while the idea of a Pacific counterpart of the Atlantic Charter is discounted, the importance of establishing cordial confidence as a basis of unity and high morale in the United Nations is emphasized. 